\title{
Multiple-criteria analysis model to the location of dry ports in urban areas: a case study in Garuva City, Santa Catarina State
}

Modelo de análise multicriterial para a locação de portos secos em áreas urbanas: um estudo de caso na cidade de Garuva, Santa Catarina

Adriana Goulart dos Santos[a] (D), Rodrigo Machado[a]

[a] Universidade do Estado de Santa Catarina (UDESC), Departamento de Engenharia Civil, Joinville, SC, Brasil

How to cite: Santos, A. G., \& Machado, R. (2020). Multiple-criteria analysis model to the location of dry ports in urban areas: a case study in Garuva City, Santa Catarina State. urbe. Revista Brasileira de Gestão Urbana, 12, e20190302. https://doi.org/10.1590/2175-3369.012.e20190302

\section{Abstract}

This article studied the location of dry ports from the perspective of reducing impacts caused by seaport activities on the urban environment. The main objective was to construct a model based on multiplecriteria decision analysis coupled with the geographical information system for selecting areas subject to the location of dry ports. An important point was the definition of restriction and factor criteria for the preparation of this model. The distance from the seaport was defined as the most relevant criterion, followed by the road hierarchy network, population density, vegetation, and declivity, respectively. The predominant restrictive criteria were: permanent conservation areas and non-building zones. For the validation of the model presented, it was necessary to perform a case study on a city located near a seaport, and that has been legalized seaport activities in its legislation. The result showed that the areas nearest to the port, with less density of household units, and located near main roadways are the most feasible for location of dry ports. It was proven that the usage of multi-criteria analysis for selecting areas subject to the location of dry ports can be a manner for added support in the preparation of master plans for cities surrounded by seaport areas.

Keywords: Dry port. Urban environment. Spatial multi-criteria analysis. Sustainable development.

\section{Resumo}

Este artigo estudou a localização de portos secos sob a perspectiva de redução dos impactos causados pelas atividades portuárias no ambiente urbano. O principal objetivo foi a construção de um modelo baseado em análise de decisão multicriterial aliado a um Sistema de Informação Geográfica para a seleção de áreas sujeitas à locação de portos secos. Um importante ponto neste estudo foi a definição dos critérios de restrição e de fatores para o desenvolvimento do modelo. A distância ao porto foi determinada como o mais relevante critério, seguida por hierarquização viária, densidade domiciliar, vegetação e declividade, respectivamente. Os critérios de restrição foram: áreas de preservação permanente e faixas não edificantes. $O$ modelo foi validado em uma cidade onde a atividade portuária é legalizada em seu plano

AGS é doutora em Engenharia Civil, professora, e-mail: adriana.santos@udesc.br

RM é mestre em Engenharia Civil, e-mail: rodrigomachado12@hotmail.com 
diretor. Os resultados mostraram que as áreas mais próximas do porto, com menor densidade populacional e mais próximas das principais rodovias da cidade são aquelas mais apropriadas para a implantação de portos secos. Ficou evidenciado que a utilização de análise multicriterial para a seleção de áreas sujeitas à implantação de portos secos pode ser um apoio adicional na elaboração de planos diretores de cidade portuárias.

Palavras-chave: Porto seco. Ambiente urbano. Análise espacial multicriterial. Desenvolvimento sustentável.

\section{Introduction}

Urban planning aims at structuring the future of the city so that no problems are generated for the population as years goes by. Planning in urban areas yields generating quality of life for the population, such as effective urban mobility, air quality, harmonious development for its environment, and efficient infrastructure networks (Souza \& Rodrigues, 2004).

When considering sustainable development in cities, the study on accessibility becomes fundamental, as it provides efficient mobility among people and cargos in urban space (Tobias et al., 2013). The concept of access or accessibility can be defined as the relationship between the daily activity in a territory and the transportation system serving said area, under the assumption that spatial interaction or reachability decreases with the increase of travel distance and time needed to reach an opportunity (Lima et al., 2019).

The value of accessibility as an integrative device, particularly in its ability to establish a connection between transportation and land use, has recently gained ground in institutions that can effectively wield it as a planning tool (Lima et al., 2019). In addition, rapid population growth and urbanization increase demands for land; hence, it is essential for government to adopt a more meaningful and practical way for land use planning and administration to have a more sustainable community (Jannet et al., 2019).

Urban planning should be aligned with the needs of the population and the decision maker must understand the urban complexity without disregarding the needs of those who live in this environment. The dynamics of cities and their evolution over time influence how people perform their daily activities. By this, accessibility must be addressed to consider the following elements: human behavior, economics, land use, and the infrastructure networks (Aragonés-Beltrán et al., 2008).

Regarding this context, those cities that focus their economic development directly linked to seaport activities deserve special attention. Seaport activities are extremely important to the development of society as it leverages the economic system and distributes the production generated in a country.

According to Gumusay et al. (2016), the most part of the human population lives in big coastal cities. More than $60 \%$ of the human population inhabits a $100-\mathrm{km}$ coastal zone, and this rate is expected to exceed $75 \%$ by 2025 . The density of population and human activities in the coastal zones can be explained by the resources provided in these areas for waste management, high accessibility and sea transportation. Coastal areas are significantly influenced by fundamental changes in the distribution of the human population due to the construction of essential infrastructure systems for sustainable residential, commercial and tourism activities (Bulleri \& Chapman, 2010).

Under these circumstances, a dry port emerges as a modern logistics center located in an inland region (Chang et al., 2015). Dry ports are commonly defined as inland terminals that have strong connections to gateway seaports by high capacity and frequent transport services (Nguyen \& Notteboom, 2016). Roso et al. (2009) defined the term dry port as an inland intermodal terminal that is directly connected to seaport(s) with high capacity transport mean(s), where customers can leave/pick up their standardized units as if directly to a seaport.

The dry port concept is based on moving intermodal terminals further inland from the port areas. This logistics platform is presented as a solution to the most important problems arising from the 
accumulation of activities in port areas: increasing road congestion, lack of open spaces in port installations and the significant environmental impact of seaports (Awad-Núñez et al., 2016).

The location of dry port must be planned before being implemented, as they can cause a big impact on the road network system of the city, causing troubles in urban mobility, changing the quality of life of the population and also causing environmental impacts.

This paper studied the location of dry ports from perspective of reducing impacts caused by seaport activities on the urban environment. Providing locations with suitable accessibility has become a growing challenge and concern for urban and regional planners. Roso (2007) commented that a successfully implemented dry port would influence a number of actors in the transportation system, such as seaport, shippers, rail operators, road operators and the whole society.

Location analysis of dry ports has received considerable attention from researchers. Most traditional mathematical methods for location analysis have been successfully applied to dry ports for specific situations. According Chang et al. (2015), among the research methods, programming methodologies such as integer programming and linear programming, as well as multicriteria decision models such as Analytical Hierarchy Process (AHP) (Gogas et al., 2014), Fuzzy Analytical Hierarchy Process (F-AHP) (Wang \& Wei, 2008) and Data Envelopment Analysis (DEA) have been used in solving the location problem (Cullinane \& Wang, 2006). Gogas et al. (2014) applied the method of multicriteria decision making to the problem of locating port logistics terminals in Greece. Nguyen \& Notteboom (2016) applied the conceptual framework for the application of multicriteria analysis to dry port location in developing countries that takes into account both quantitative and qualitative criteria relevant to a range of stakeholders. In Spain, Awad-Núñez et al. (2016) investigated the variables influencing sustainability of dry port location and how this sustainability can be evaluated. Abbasi \& Pishvaee (2018) investigated the location of dry ports by providing a two-stage GIS-optimization model. The obtained numerical results indicated that the use of the developed model and establishment of the dry port led to the reduced costs, reduced variable environmental effects of the seaport, improved accountability to the customers of these ports, and consequently increased competitiveness. Notteboom (2011) applicated of multi-criteria analysis (MCA) to the evaluation of three alternative locations for the development of a large hub port in the South African container port system.

The Greenfield analysis was used by Saad \& Bahadori (2019) to identify the optimal number and location of facilities with different service constraints. This method of analysis is quite frequently used in industry to determine the best location for a new and existing facility by which the location is indicated by latitude and longitude. Muravev et al. (2020) presented the application of the hybrid DEMATELMAIRCA model to select the optimal locations of the CR Express international logistics centers (CILC). The DEMATEL method was applied to identify the weights of the criteria. The multiatributive ideal-real comparative analysis (MAIRCA) method was applied to evaluate the alternatives and select the locations of precandidate cities for CILC. According this autors, the DEMATEL-MAIRCA is less sensitive to changes in the weights of selected criteria and related changes in alternative ranking.

In another study, Muravev et al. (2019) affirmed that researchers in the field of intermodal transportation have studied only the impact of individual factors on the efficiency of the dry port operation, or mutual influence of no more than two factors. For example, how the intensity of traffic volume affects the storage capacity of the dry port or how the distance between a seaport and a dry port could impact the irregularity of traffic volume. This autors presented an approach to systemizing factors that have a significant impact on issues related to the dry port's construction and efficiency of its operation, i.e., how the environmental factor could influence the intensity of traffic volumes or what is the interrelation between irregular traffic and distance between two terminals.

However, none of the existing research took into consideration of reducing impacts caused by seaport activities on the urban environment when studying the problem of locating dry ports.

This study focused multiple-criteria decision analysis (MCDA) approach as the number of potential locations for dry port planning is finite due to the high requirements linked to a dry port site in terms of land use availability and suitability. MCDA has grown as a part of operations research, concerning with 
designing computational and mathematical tools for supporting the subjective evaluation of performance criteria by decision makers (Mardani et al., 2015). The MCDA methods aim to aid decision makers in accordance with certain criteria to select the best alternative among several options. Analytic hierarchy process (AHP), which is a commonly used MCDA method, resolves complex multicriteria problems into a hierarchical structure (Gumusay et al., 2016). The AHP method uses linear algebra to formulate hierarchical structures, matrices and decision steps (Saaty, 1980).

In this context, the main objective this study was to construct a model based on multiple-criteria decision analysis coupled Geographical Information System (GIS) for selecting areas subject to the location of dry ports. The model proposes to aid city planners and public administrators in legally allocating territories in seaport cities, as well as providing for investors subsidies for decision-making regarding the acquisition of a given land for location a dry port.

GIS tool is a set of computer hardware and software which is used to process and store the spatially referenced data to derive information. One of the key applications of GIS is land suitability analysis targeting the identification of appropriate spatial configurations for upcoming land uses based on specific criteria and requirements (Dhiman et al., 2018). Specific land suitability applications of GIS include urban and regional planning (Parry et al., 2018), selecting site for public and private sector facilities (Bencure et al., 2019; Zhu et al., 2019), accessibility and sustainability (Lima \& Machado, 2019; Felix et al., 2019), environmental impact assessment (Kaim et al., 2018; Lyu et al., 2018), coastal vulnerability assessment (Dhiman et al., 2018).

According to Malczewski (2004) GIS plays a vital role in planning for many decades of land-use suitability mapping and modelling. Suitability analysis in a GIS context or GIS-based is a geographic process used to determine the appropriateness of a given area for a particular use. The basic premise of GIS suitability analysis is that each aspect of the landscape has intrinsic characteristics that are to some degree either suitable or unsuitable for the activities being planned. Suitability is determined through systematic, multi-factor analysis of the different aspects of the problem. A GIS suitability model typically answers the question: where is the best location? Land suitability analysis is used for site selection, impact studies and land use planning (Kaiser et al., 1995).

For the validation of the model presented in this study, it was necessary to perform a case study on a city located near a seaport, and that has legalized seaport activity in its legislation. Thus, the city of Garuva in state of Santa Catarina, Brazil, was selected, due to the fact of being the main access to the Itapoá Port and also the large-scale availability of areas suitable for the implementation of dry ports in its master plan. The master plan has mapped areas that are recommended as Special Zones for Industrial and Logistic Predominance. So, the dry ports could potentially improve the social and economic indicators of a region where intermodal terminals would be located.

Itapoá Seaport started operations in June 2011, being considered one of the most agile and efficient terminals in Latin America and one of the largest and most important in the country in handling containerized cargo. The Itapoá Seaport has a current capacity for handling 500 thousand TEUs (Twenty Foot Equivalent Units) (the cargo capacity in a normal maritime container - 20x8x8 feet) per year and there is a forecast of expanding that to 2 million TEUs per year. The Itapoá Seaport presents in terms of the predicted demand for transport and logistics services, the increases the cargo volume by intermodal transportation.

\section{Methods}

The method applied for the development of the model is divided into four steps: 1) study area characterization; 2) define criteria; 3) analytic hierarchy process; and 4) spatial analysis of the GIS-based. The flowchart displayed in Figure 1 shows the steps performed for the development of the model. 


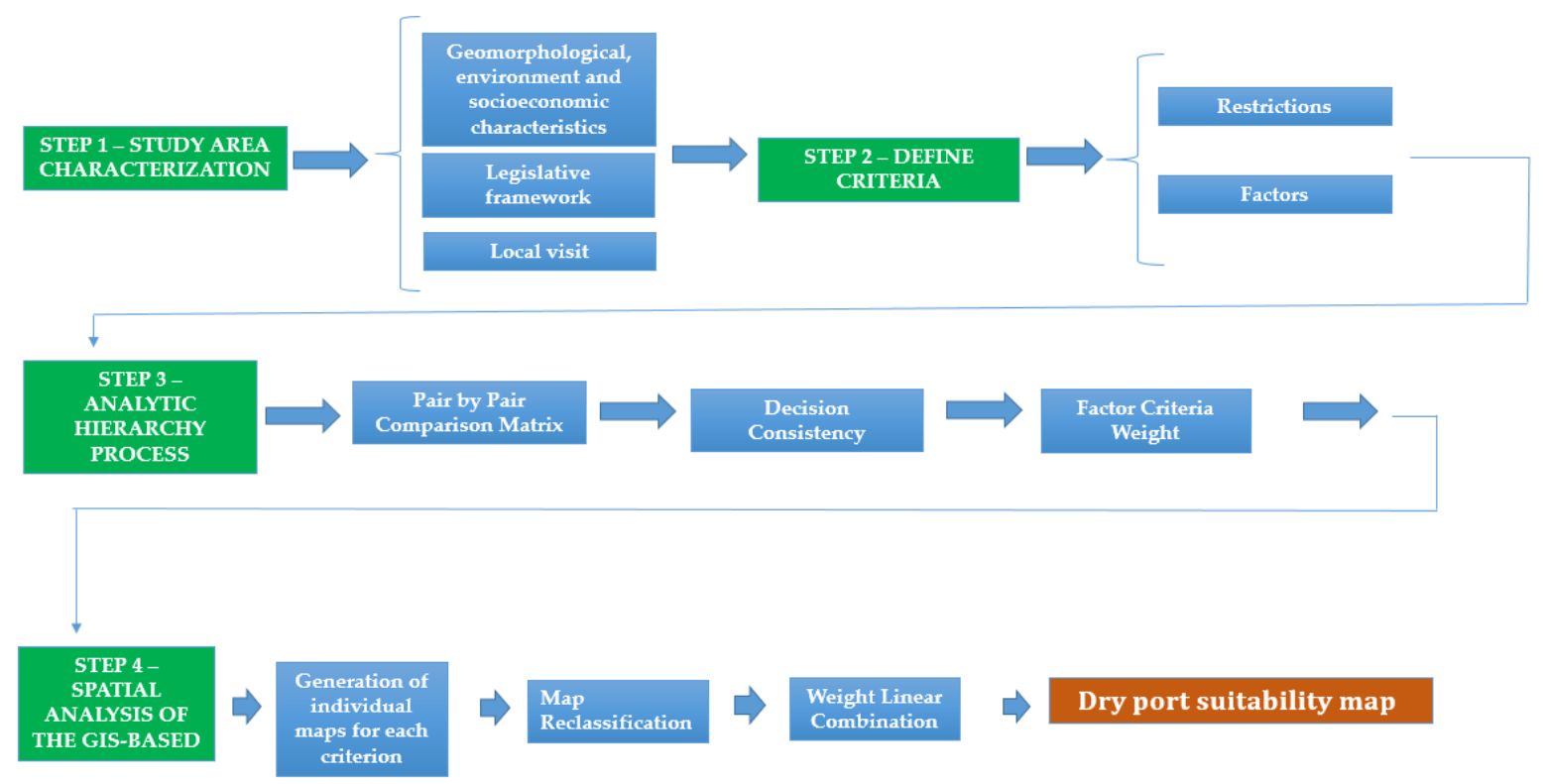

Figure 1 - Flowchart on steps for the development of the model. Source: The authors.

\section{Study area characterization}

The dry port siting task necessitates taking account of a large number of spatially related factors to guarantee the efficiency of the dry port facilities. However, this efficiency depends the geomorphological, environment and socioeconomic characteristics of the candidate area as well as the existing legislative framework. The dry port site selection problem demands the implementation of criteria that are related to the examined area's characteristics.

\section{Define criteria}

The fundamental step in site selection was the determination of criteria to assess the suitability of land to gain the objectives. The criteria were chosen according to the characterization of study area performed in step 1 and that might have influence on a dry port location. In this study, seven criteria were selected and classified into two groups: restrictions and factors. The restriction criteria are eliminatory, which means, the restriction criteria display a null weight, thereby defining such an area being unfit to be utilized as a dry port. Since factor criteria are selective, which means, they display an importance level or weight, defined by means of the Analytical Hierarchy Process (AHP) (Saaty, 2008).

The restriction criteria selected were:

- Permanent Conservation Areas: Some lands such as protected areas, dense forests, and water bodies cannot be used for the installation of developments. According to national legislation 4.771 (Brasil, 1965) in Brazil, a permanent conservation area is defined as a place that may be covered or not by native vegetation, for the environmental purpose of conserving water resources, landscape, geographical stability, biodiversity, genic flow of fauna and flora, protection of the soil and assure the well-being of human population;

- Non-building Zones: Nonbuilding zones are areas where not possible the location of developments, due to some interference in the land, such as high-tension electric networks and soil gas pipelines.

The factor criteria selected were: 
- Declivity: Declivity zones are separated according to classifications defined by Ramalho \& Beek (1995). The authors established declivity class intervals according to the limitation level of soil usage based on erosion. This interval scale is divided as: flat/practically flat ( 0 to $3 \%$ declivity), slightly hilly ( 3 to $8 \%$ declivity), moderately hilly (8 to $13 \%$ declivity), hilly (13 to $20 \%$ declivity), extremely hilly (20 to $45 \%$ declivity), and mountainous (over $45 \%$ declivity).

For the economic construction of dry ports, the flatter the land is the more recommended for the establishment of these ports. According to Ramalho \& Beek (1995) classifications, declivity zones were generated and then attribute sub-factors to each one of them. The importance factor for the flat zone is 1 . The slightly hilly zone is 0.8 , the moderately hilly zone is 0.6 , the hilly zone is 0.4 , extremely hilly zone is 0.2 , and the mountainous zone does not add any value at all.

- Vegetation: According to national legislation 11.428 (Brasil, 2006) in Brazil, vegetation can be classified as medium stage vegetation, when it is possible to suppress up to $70 \%$ of the area, the advanced stage is when it is permissible to cut a maximum of $50 \%$ of the vegetation. But those areas must be compensated in another location. One can suppress $100 \%$ of the vegetation when the vegetation is in the initial stage.

Four classes have been defined for this criterion: advanced stage vegetation, medium stage vegetation, initial stage vegetation, and soil without any vegetation coverage.

According to this rationale, the more vegetation that can be suppressed, the more useful the area is for location a development. As the criterion was divided into four classes, the sub-factor for soil without any vegetation coverage is 1 , initial stage vegetation is 0.75 , the medium stage is 0.50 , and advanced stage vegetation is 0.25 .

- Road Hierarchy Network: The road hierarchy network ranking was divided into three classes: main roadway, secondary access roadway, and restricted access roadway.

The main roadway class is made up of large-scale roads and specific routes assigned to seaport transport. Whereas, secondary access is defined by the capability of access to large-scale vehicles, but not included in dry ports main access, such as roadways in industrial centers. Finally, restricted access roadways are made up of urban roads, with predominately residential traffic, where intense large-scale vehicles will negatively impact urban mobility.

Sub-factor is 1 for the main roadway, whereas secondary access roadway sub-factor is 0.77 and, restricted access sub-factor is only 0.33 .

- Distance from Seaport: The proximity to seaport is of great importance because long distances would result in very high costs for containers transportation. Distances from the seaport were defined for location of dry ports. The following intervals were applied for ranking distances: 0 to $5 \mathrm{~km}$ (the sub-

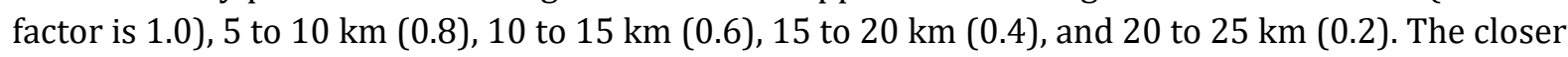
the land is to the seaport the criterion is attributed to a higher sub-factor;

- Population Density: Considering the environmental issues and other features of dry ports, including reduction of traffic, it is better to construct these ports at places with fewer problems in terms of land use. One of the functions of dry ports is to remove containers from the port city and help reduce traffic in cities. In this context, the population density refers to the average number of households per square area in a given location and, it is generally measured by the ratio of households per square kilometer.

For quantifying that criterion, the existing constructions must be considered in the location where the dry port will be constructed. On the greater the number of existing constructions there is, the lower its ranking will be for approving the development. This criterion divided the areas into five classes: nondensified areas, the sub-factor is equal to 1.0 , low densified areas, sub-factor is 0.8 , densified areas (0.6), highly densified areas (0.4), and extremely densified areas, whereas there is no importance factor for this criterion, and therefore the sub-factor is equal to 0.0 . 


\section{Analytic Hierarchy Process (AHP)}

Determination of the weights for the factor criteria was performed through the Analytical Hierarchical Process, with the scale composed of nine numerical levels (Saaty, 1980). Through this technique, weights and priorities are derived from a set of judgments provided by expert's views (city planners, public administrators and investors). The application of the method was performed by comparing the pairs of criteria in the nxn matrices.

The twelve evaluators made their judgments, assigning importance and values to the criteria. From these persons' points of view, the distance from seaport present a higher weight than the other criteria. They pointed out this category as the most important factor for accessibility, with a weight equal to 0.416 , as shown in Figure 2. Road Hierarchy Network were placed in the second position, with a weight of 0.249, followed by population density, with a weight of 0.157 and the vegetation and slope being the least important, with a weight of 0.123 and 0.055 , respectively.

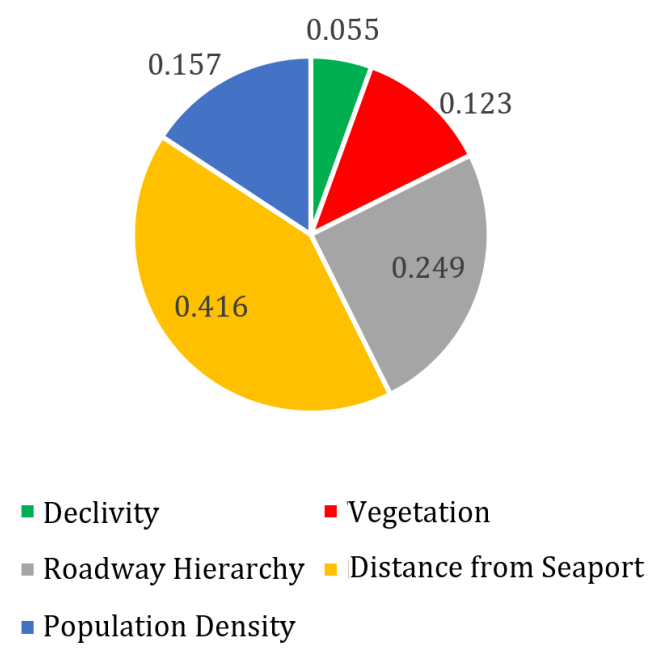

Figure 2 - Factor criteria weight. Source: The authors.

\section{Spatial analysis in a Gis-based}

The final step is producing the final dry port suitability map by overlaying the factor and restriction criteria maps. In this study, weight linear combination (WLC) method was utilized to aggregate the maps. The WLC is ease of use in GIS-based, and it is the most common technique in multi-criteria decision analysis. Finally, after merging the layers, the suitable points for establishing the dry port are identified and given to the model as the potential points.

\section{Case study}

\section{Study area: Garuva City, Brazil}

The Brazilian coastal zone is a territorial unit extending, in its terrestrial portion, over $8,500 \mathrm{~km}$ encompassing 17 states, and there are over four hundred towns and cities, spread from the northern equatorial region to the temperate southern part of the country. Brazil has a great potential for maritime transport, due to this vast coastal zone (Novaes \& Vieira, 1996). 
National Waterway Transportation Agency (ANTAQ, 2016) is the entity defining the classification of Public Ports, Private Operated Terminals, and Cargo Transshipment Stations, and confirms there are 235 (two hundred and thirty-five) port facilities in the Brazil.

The model was validated based on its application in the Garuva City, Brazil. Garuva City is in the northern part of Santa Catarina State, in southern Brazil, has a territorial area 503,595 km², with 17,800 inhabitants and a population density of 29.41 inhabitants $/ \mathrm{km}^{2}$. The location of Garuva city and the study area are showed in Figure 3 and Figure 4, respectively.

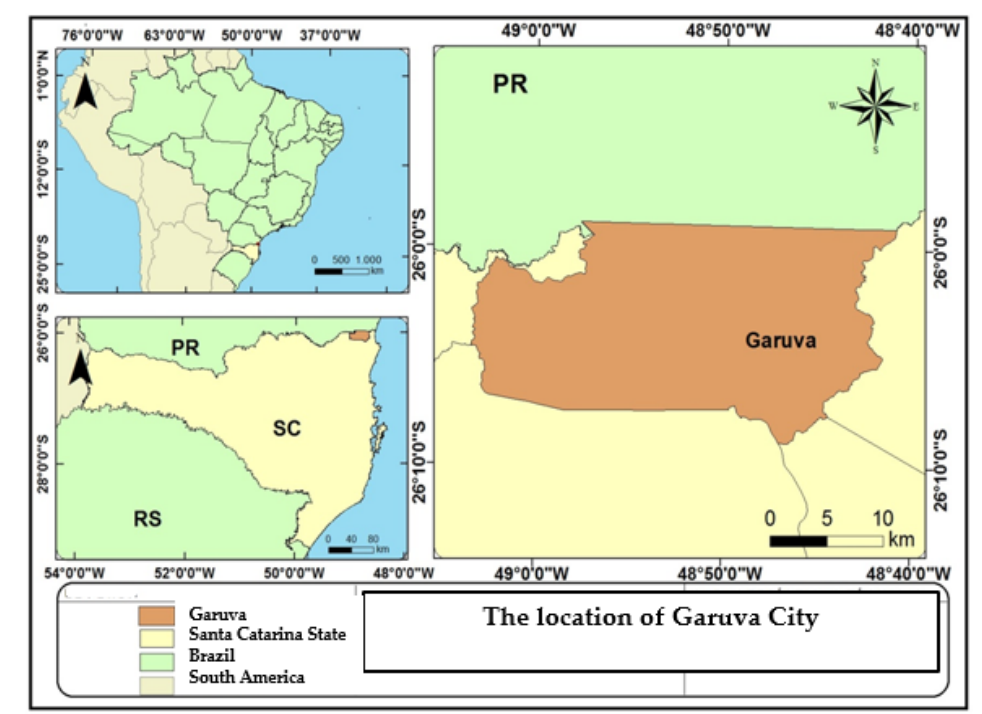

Figure 3 - The location of Garuva City, Brazil. Source: The authors.

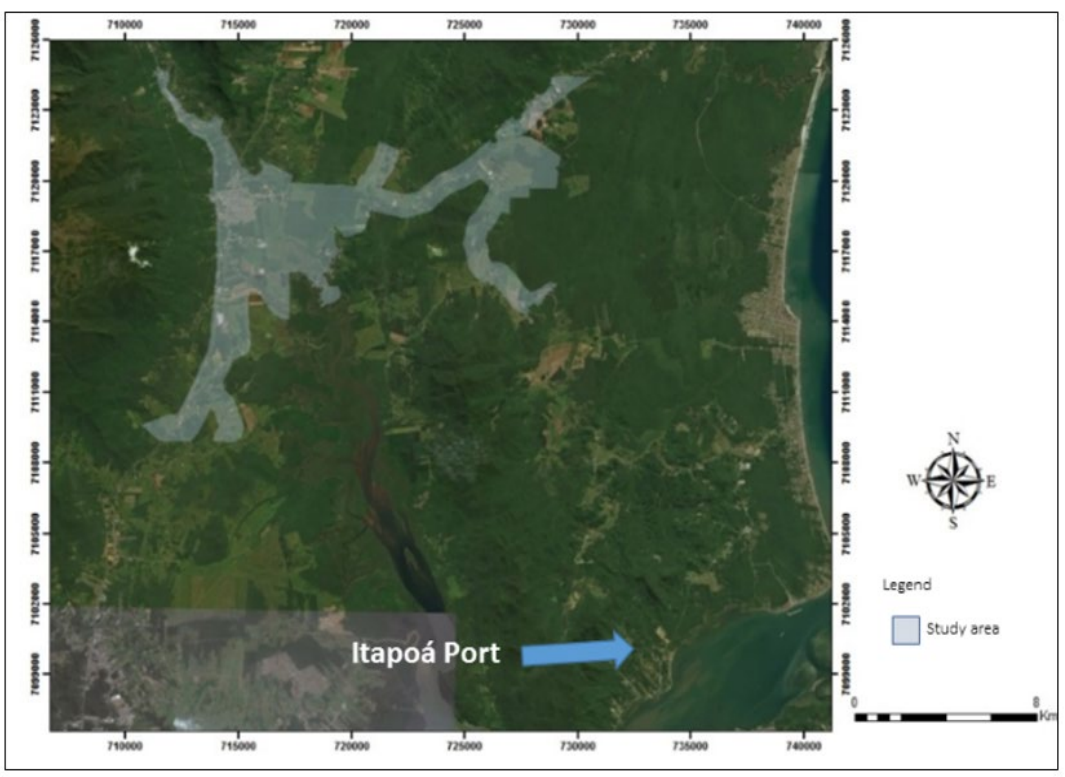

Figure 4 - Study Area. Source: The authors.

\section{Data and spatial processing}

The information layers of the criteria were prepared using ArcGIS 10.2. Table 1 presents the description and sources of spatial data used in the case study. 
Table 1 - Spatial Data

\begin{tabular}{|c|c|c|c|}
\hline Criterion & Spatial Data & Source & Format \\
\hline Permanent Conservation Area & Hydrography & $\begin{array}{c}\text { Santa Catarina State Development } \\
\text { Secretariat - SDS }\end{array}$ & Shapefile \\
\hline $\begin{array}{l}\text { Oil Pipes } \\
\text { High Tension Zone }\end{array}$ & $\begin{array}{l}\text { Oil Pipelines } \\
\text { High Tension Lines }\end{array}$ & $\begin{array}{l}\text { Ciram } \\
\text { Ciram }\end{array}$ & $\begin{array}{l}\text { Shapefile } \\
\text { Shapefile }\end{array}$ \\
\hline Declivity & $\begin{array}{l}\text { Land Numerical } \\
\text { Model }\end{array}$ & IBGE & Shapefile \\
\hline Population Density & $\begin{array}{l}\text { Residence Unit } \\
\text { Points }\end{array}$ & Ciram & Shapefile \\
\hline Road Hierarchy Network & $\begin{array}{l}\text { Road Network } \\
\text { System }\end{array}$ & Garuva City Hall & Dwg \\
\hline Vegetation & Satellite Image & Google Earth & Jpeg \\
\hline Population Density & $\begin{array}{l}\text { Residence Unit } \\
\text { Points }\end{array}$ & Ciram & Shapefile \\
\hline
\end{tabular}

The restriction criteria are permanent conservation areas and non-building zones. Local visits were performed in the study area in order to verify the existence of locals where oil pipelines cross as well as electric high-tension power networks; these locations are characterized as non-building zones. Spatial data was collected from Environmental Resources and Hydrometeorology Information Center of Santa Catarina State (CIRAM), where high-tension power lines and petroleum and natural gas pipelines were registered. Pipelines and power networks were identified on the map, and thereafter $20 \mathrm{~m}$ buffers-zone were generated, forming non-building zones as presented in Figures $5 \mathrm{a}$ and $5 \mathrm{~b}$, respectively.

Based on the data supplied by the Santa Catarina State Development Secretariat (SDS), where all the water resources in Santa Catarina State have been mapped, it was possible to prepare a restriction map showing permanent conservation areas. Thirty-meter buffers-zone were generated for all the water resources registered by SDS, for mapping all permanent conservation areas (Figure 5c).

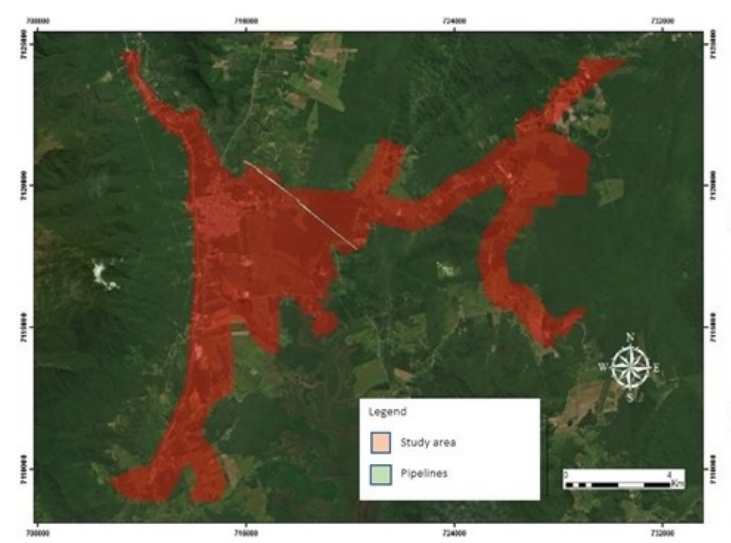

(a)

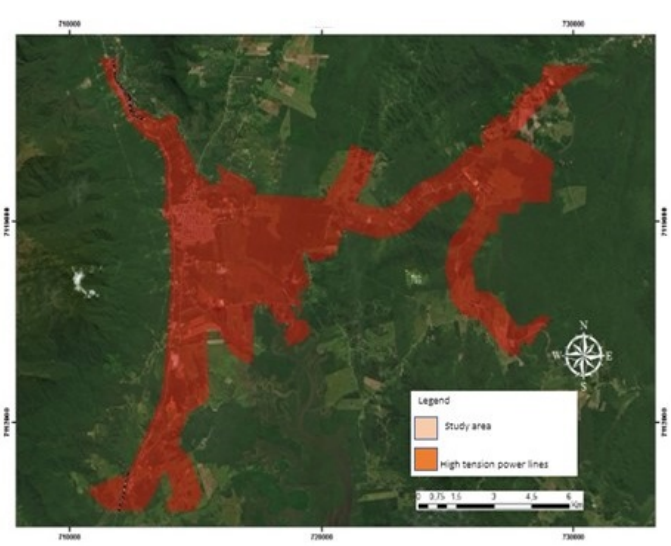

(b)

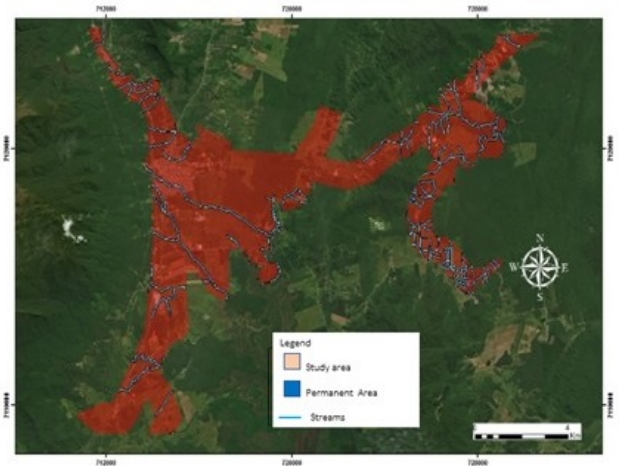

Figure 5 - The individual restriction factor maps: (a) Pipelines; (b) Power networks; (c) Permanent Conservation Area. Source: Elaborated by the authors. 
Household unit points were obtained by CIRAM. Those points were acquired from a shapefile format and imported into SIG ArcGis 10.2. Using the household unit points in the study area the population density map was generated by SIG, using the point density tool. Household density was divided into five classes: non-densified areas, low densified areas, densified areas, highly densified areas, and extremely densified areas (Figure 6a).

The declivity map was generated by the digital elevation model (DEM) of study area. The DEM was imported to SIG ArcGis 10.2 and using on the "create TIN" function, declivity map was generated. The declivity map was divided into six classes: flat, slightly hilly, moderately hilly, hilly, extremely hilly, and mountainous (Figure 6b).

The road hierarchy network was generated by the roadway system supplied by the Garuva Municipal City Hall. This network was defined on basis on the functionality of the roads for dry ports activities and its interferences on the urban environment. Accessibility to roads was also taken into account: type of road access (conventional, highway), distance to the nearest highway, number of lanes of the access road, Average Daily Traffic (ADT) and Level of Service (LOS) of the path. The best locations have direct access to routes with good infrastructure conditions and a level of service that allows heavy vehicles to circulate efficiently. Buffers-zones of 300 meters were created along the main road and secondary access to define its influence areas. A distance of 300 meters was considered for the buffers to serve the purposes of DIA (direct influence areas) and IIA (indirect influence areas) of the roadway. The residential roads were classified as restricted access area (Figure 6c).

The vegetation map was generated from a georeferenced satellite image. For this, the Google Earth source was selected due to the actuality of the image, of year 2018. After the image was properly georeferenced, the soil classification was performed, focused on the vegetation. That procedure was based on the classification of the supervised image, according to the following classifications: advanced stage vegetation, medium, initial, and soil without any vegetation coverage. Samples of vegetable were selected and, verified in the field, in the stage the vegetation was found (Figure 6d).

The distance from the seaport map was prepared considering the distance traveled to arrive at the dry port. That distance was calculated based on the road classification in the road hierarchy network criterion. Routes were mapped by the roads defined as main roads and secondary access. Those routes were mapped automatically by using the "reconstruct route" function in SIG ArcGis 10.2. The distance was divided into 5-kilometer zones.

According to the defined routes, a maximum distance of 25 kilometers was confirmed from the closest location to the port to the furthest (within the studied area). Thus, 5 distance classes were generated to the seaport: 0 to $5 \mathrm{~km}, 5$ to $10 \mathrm{~km}, 10$ to $15 \mathrm{~km}, 15$ to $20 \mathrm{~km}$, and 20 to $25 \mathrm{~km}$ (Figure 6e).

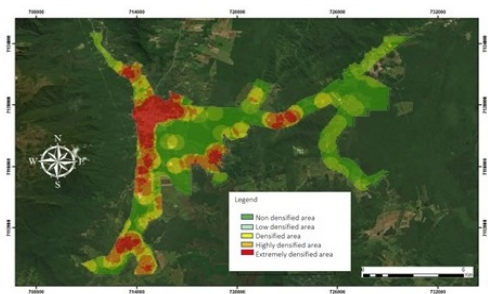

(a)

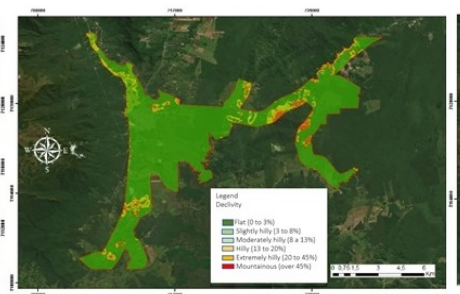

(b)

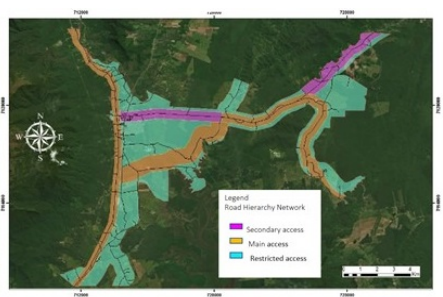

(c)

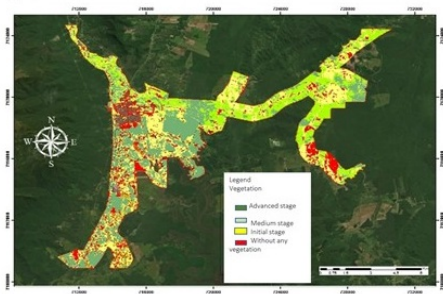

(d)

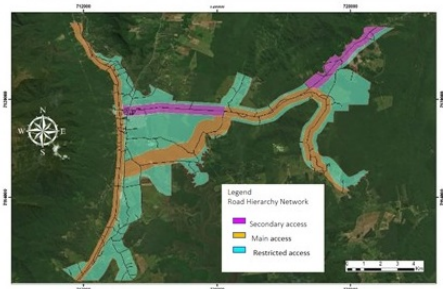

(e)

Figure 6 - The individual criteria factor maps: (a) Population Density; (b) Declivity; (c) Road Hierarchy Network; (d) Vegetation; (e) Distance from Seaport. Source: Elaborated by the authors. 


\section{Weight linear combination}

After each of the maps on factor and restriction criteria has been generated, it was necessary to combine all the maps into a one, by applying the weight for each criterion.

The concept of the weight linear combination was used, supported by SIG ArcGis. The first procedure was to reclassify the maps individually, so that, it was necessary to apply the respective weight to each criterion, as according Figure 2.

This procedure was performed by employing the "Reclassify" function. It was possible to rank the subfactor criteria in this ArcGis function. This procedure was repeated for all the criteria.

The next procedure was to combine the criterion maps. The "Raster Calculator" function was used for this purpose. Using this function, it was possible to set up a mathematic model for combining the maps. Abiding by the importance level as seen in Figure 2, the following Equation 1 was used for combining the criteria.

$(0.055 \times$ Declivity $)+(0.123 \times$ Vegetation $)+(0.249 \times$ Road Hierarchy Network $)+$

$(0.416 \times$ Distance from the Seaport $)+(0.157 \times$ Population Density $)=$ Dry port suitability map

Thus, all the criteria were combined based on their weight. Finally, the criteria were inserted restricting the occupation of a given area for the location of the dry ports. Figure 7 shows the map describing the restricted areas, as well as those that are more feasible or less feasible for the location of dry ports in the urban area in the city of Garuva.

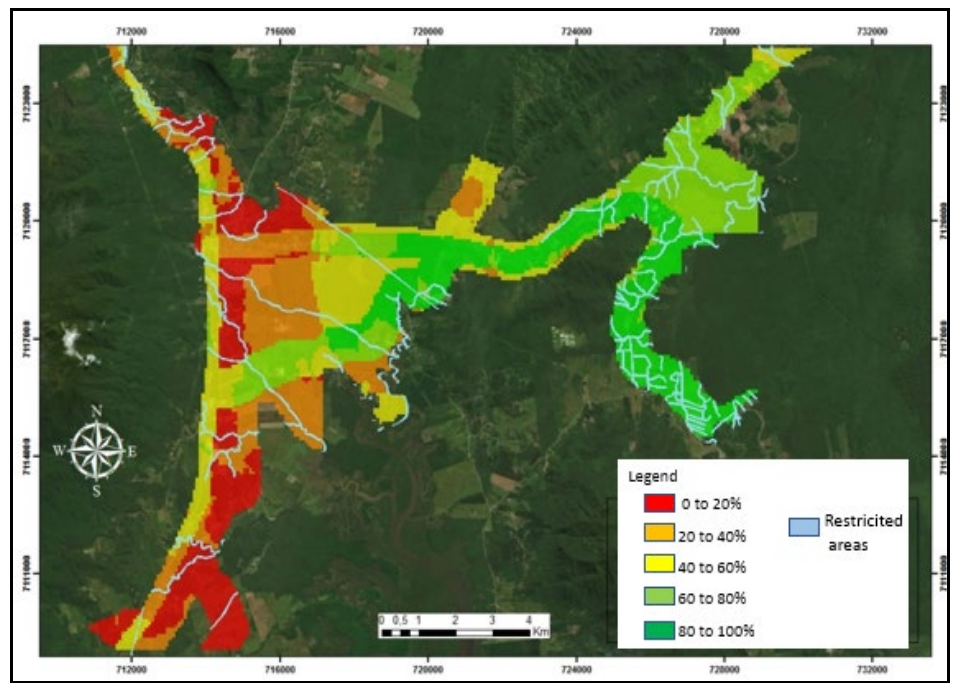

Figure 7 - Dry port suitability map - Case study in Garuva City, Brazil. Source: Elaborated by the authors.

\section{Discussion}

In this study, the restriction and factor criteria were defined for the model construction for to the location of dry ports in urban areas.

The AHP model was applied by pairwise comparison matrix to determine the weighting of factor criteria which forms a solution of this problem. According to the AHP results, the importance or weights of the five-factor criteria is indicated by the real opinion of the city planners, public administrators and investors. The distance from seaport (weight 0.416 ) is the most important factor that influences land accessibility, while road hierarchy network (weight 0.249 ) and population density (weight 0.157 ) factors are moderately important. This indicates that experts placed more emphasis on criteria related on 
impacts that dry ports can be cause in the urban environments as also reported by previous studies (Roso et al., 2009; Roso, 2007; Awad-Núñez et al., 2016).

The criteria related to the accessibility to a transport mode measure how easily different inland transport infrastructures can be accessed from the dry port location (Chang et al., 2015). For road transport, was considered the distance to the nearest highway exit, average daily traffic and level of service.

By other hand, the vegetation (weight 12.133) and declivity (weight 5.53) refers physical attributes and are less important factors in interferences on the urban environment. This is quite realistic because in general, the experts do focus on accessibility benefits of dry ports.

Based in these factors and on the map shown in Figure 7, the green areas are more feasible for the location of dry ports and the red areas are less feasible for the location of those developments. Figure 8 shows where the most feasible areas for dry ports location. These areas were selected based on factors criteria: they are near to main roads for accessing the port, located near the seaport, and there are not many population density nearby.

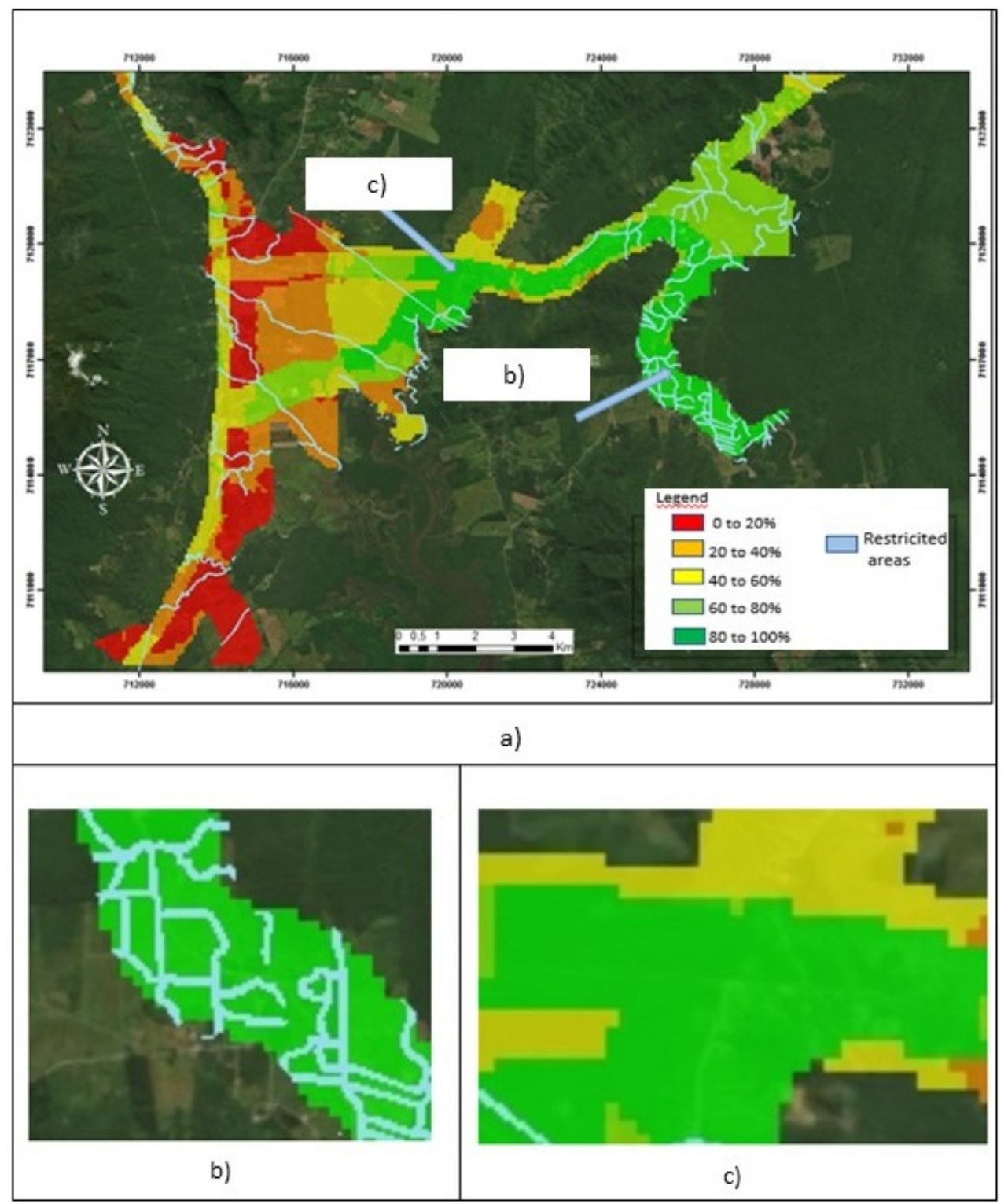

Figure 8 - (a) Dry port suitability map; (b) Area with many restrictions; (c) Area with few restrictions. Source: Elaborated by the authors. 
In Figure $8 \mathrm{~b}$ it is possible to see that although the area be optimally used for dry ports, that location show a greater number of restriction points (permanent conservation areas), that will prevent the location of ports that requires large continuous areas. Figure 8c displays the best areas for the dry port location, as there are few restriction areas.

There are areas that are not recommended for the implementation of dry ports. These areas are concentrated in a location distant from the seaport and provide a deficient roadway infrastructure (Figure 9b). The worst areas for the location of this type of development are located in downtown Garuva, as these areas provide restricted mobility for heavy vehicles and they are also far from the seaport, this region is extremely densified in population, as shown in Figure 9c.

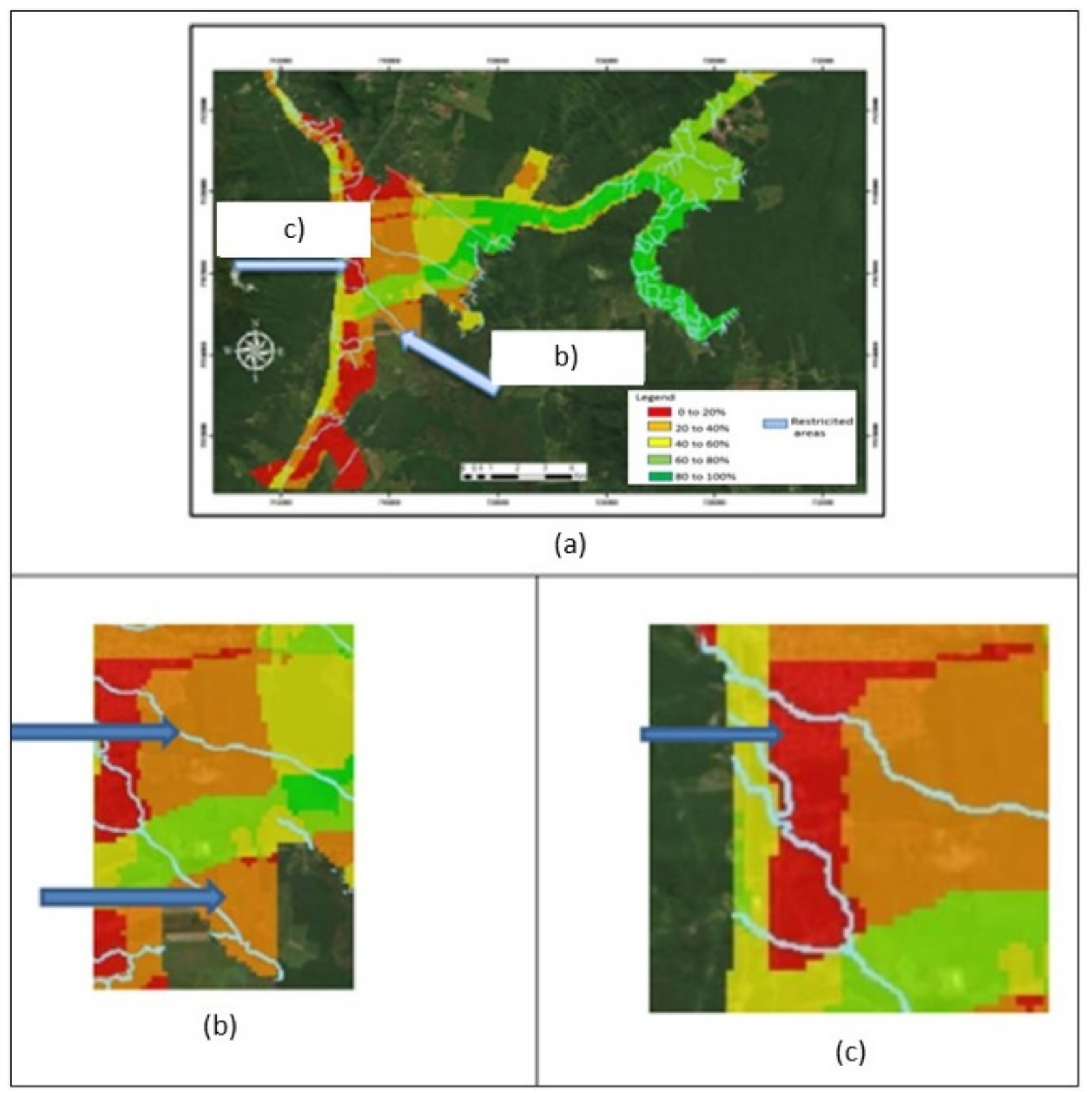

Figure 9 - (a) Dry port suitability map; (b) Area with little mobility; (c) Downtown of the Garuva City. Source: Elaborated by the authors.

Another important subject for discussion is the comparison of the map generated in this case study to the actual land-use and occupation map of Garuva City, both of these are shown in Figure 9. 


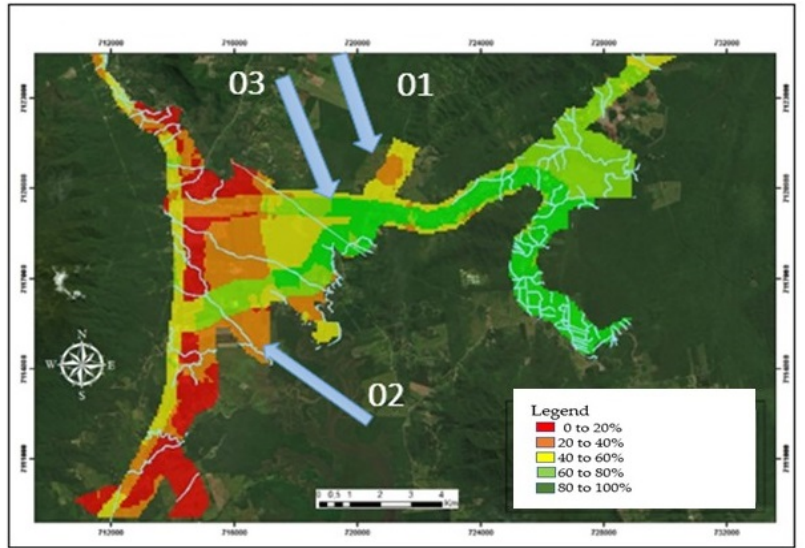

(a)

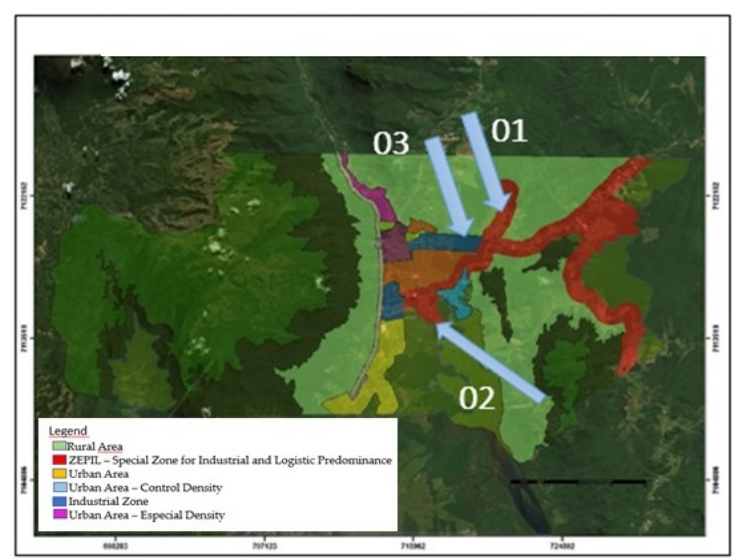

(b)

Figure 10 - (a) Dry port suitability map; (b) Land-use map of Garuva City. Source: Elaborated by the authors.

By analyzing Figure 10b, in the land-use and occupation map of Garuva City, the dry ports location (represented by the red color), are represented along the main access roads to the port. However, there are some points that must be discussed:

- The area shown in point 01 on Figure 10a was selected as a medium and low priority area for the location of dry ports. However, in the land-use and occupation soil map of Garuva City (Figure 10b) it is an area where the location of dry ports is permitted;

- In point 02 , shown in Figure $10 a$, is an area where there is little feasibility for the location of dry ports. Clearly, this area does not display any possibility for roadway infrastructure for the purpose of setting up any type of large-scale development, even though on the Master Plan of the Garuva City, this area is defined as ZEPIL - Special Zone for Industrial and Logistic Predominance;

- In point 03, shown in Figure 10a, the area has been selected as feasible for the location of dry ports, however, in the current legislation, that standardizes the land-use and occupation, this area is not included in a zoning area making it possible to location of dry ports.

It was confirmed that the Master Plan of the city did not map restricted areas as specified in this study, even though those areas were guaranteed by legislation. It was also confirmed that the Master Plan of Garuva City mapped areas that are not clearly recommended as Special Zones for Industrial and Logistic Predominance.

\section{Final consideration}

The model's application in case study presented great contribution to the studied region in South Brazil, and the results have some policy implications in terms of urban planning and sustainable urban mobility in cities surrounded by seaports. The results shown that the model added support in the preparation of Master Plans for these cities and proving to be an important tool to aid decision-making.

A dry port must fit into a complex system where exist on the necessary infrastructure, land-use planning, environmental protection, and that the legislative, regulatory, and institutional systems will be properly designed to optimize the involvement of both the public and the private sector.

This study presented factors that influence implementation of a dry port such as: infrastructure, landuse, environment, regulations. The model does not considerately the actors that are influenced by a dry port: seaport, road operators, rail operators, shippers, society. However, even without considering these additional attributes, the result of the model application, when compared to on-site observation, demonstrated coherence with the city's actual situation. 
A very important conclusion is that the satisfactory results allow to confirm the great power of applying Multi-criteria Decision Analysis to the assessment of dry port location and consequently of sustainable development of the urban environment.

The developed model can be applied in other urban areas subject to the location of dry ports in the Brazil. Since the legal factors or conditions set in this study were based on the laws of Brazil, the model may be modified slightly for application in urban areas of other countries.

Moreover, in studies futures, the environmental effect should be considered in the selection of the optimal dry port's location, including carbon dioxide $\left(\mathrm{CO}_{2}\right)$ emissions, noise, accidents and congestion from generated road traffic.

\section{References}

Abbasi, M., \& Pishvaee, M. (2018). A two-stage GIS-based optimization model for the dry port location problem: a case study of Iran. Journal of Industrial and Systems Engineering, 11(1), 50-73.

Agência Nacional de Transportes Aquaviários - ANTAQ. (2016). Estatísticas. Retrieved in 2018, September 12, from http://web.antaq.gov.br/Portal/PDF/Anuarios/ApresentacaoAnuario2016.pdf

Aragonés-Beltrán, P., Aznar, J., Ferrís-Oñate, J., \& García-Melón, M. (2008). Valuation of urban industrial land: an analytic network process approach. European Journal of Operational Research, 185(1), 322-339.

http://dx.doi.org/10.1016/j.ejor.2006.09.076.

Awad-Núñez, S., González-Cancelas, N., Soler-Flores, F., \& Camarero-Orive, A. (2016). A methodology for measuring sustainability of dry ports location based on Bayesian Networks and Multi-Criteria Decision Analysis.

Transportation Research Procedia, 13, 124-133. http://dx.doi.org/10.1016/j.trpro.2016.05.013.

Bencure, J., Tripathi, N., Miyazaki, H., Ninsawat, S., \& Kim, S. (2019). Development of an Innovative Land Valuation Model (iLVM) for mass appraisal application in sub-urban areas using AHP: an integration of theoretical and practical approaches. Sustainability, 11(13), 3731. http://dx.doi.org/10.3390/su11133731.

Brasil. (1965, 15 de setembro). Lei no 4.771, de 15 de setembro de 1965. Brasília: Diário Oficial da União. Retrieved in 2019, February 11, from www.mma.gov.br/port/conama/processos/E72A2846/DispositivosLegaisAPP.pdf

Brasil. (2006, 22 de dezembro). Lei no 11.428, de 22 de dezembro de 2006. Brasília: Diário Oficial da União. Retrieved in 2018, October 9, from www.planalto.gov.br/ccivil_03/_ato2004-2006/2006/lei/111428.htm

Bulleri, F., \& Chapman, M. G. (2010). The introduction of coastal infrastructure as a driver of change in marine environments. Journal of Applied Ecology, 47(1), 26-35. http://dx.doi.org/10.1111/j.1365-2664.2009.01751.x.

Cullinane, K., \& Wang, T. F. (2006). Chapter 23 Data Envelopment Analysis (DEA) and improving container port efficiency. Research in Transportation Economics, 17, 517-566. http://dx.doi.org/10.1016/S0739-8859(06)17023-7.

Chang, Z., Notteboom, T., \& Lu, J. (2015). A two-phase model for dry port location with an application to the port of Dalian in China. Transportation Planning and Technology, 38(4), 442-464.

http://dx.doi.org/10.1080/03081060.2015.1026103.

Dhiman, R., Kalbar, P., \& Inamdar, A. B. (2018). GIS coupled multiple criteria based decision support for classification of urban coastal areas in India. Habitat International, 71, 125-134.

http://dx.doi.org/10.1016/j.habitatint.2017.12.002.

Felix, R. R. O. M., Alves, V., \& Lima, J. P. (2019). Gestão do uso do solo no entorno do Rio Sapucaí em Itajubá (MG). urbe. Urbe. Revista Brasileira de Gestão Urbana, 11, e20170180. http://dx.doi.org/10.1590/21753369.011.001.ao02.

Gogas, M., Papoutsis, K., \& Nathanail, E. (2014). Optimization of decision-making in port logistics terminals: using analytic hierarchy process for the case of port of Thessaloniki. Transport and Telecommunication Journal, 15(4), 255-268. http://dx.doi.org/10.2478/ttj-2014-0022. 
Gumusay, M. U., Gokalp, K., \& Tolga, B. (2016). An assessment of site suitability for marina construction in Istanbul, Turkey, using GIS and AHP multicriteria decision analysis. Environmental Monitoring and Assessment, 188(12), 677. http://dx.doi.org/10.1007/s10661-016-5677-5. PMid:27858260.

Jannet, C. B., Nitin, K. T., Hiroyuki, M., Sarawut, N., \& Sohee, M. (2019). Development of an Innovative Land Valuation Model (iLVM) for mass appraisal application in sub-urban areas using AHP: an integration of theoretical and practical approaches. Sustainability, 13(11), 1-17. http://dx.doi.org/10.3390/su11133731.

Kaim, A., Cord, A., \& Volk, M. (2018). A review of multi-criteria optimization techniques for agricultural land use allocation. Environmental Modelling \& Software, 105, 79-93. http://dx.doi.org/10.1016/j.envsoft.2018.03.031.

Kaiser, E., Godschalk, D., \& Chapin, S. (1995). Urban land use planning (4th ed.). Chicago: University of Illinois Press.

Lima, J. P., \& Machado, M. H. (2019). Walking accessibility for individuals with reduced mobility: a Brazilian case study. Case Studies on Transport Policy, 7(2), 269-279. http://dx.doi.org/10.1016/j.cstp.2019.02.007.

Lima, J. P., Abitante, J. C., Pons, N. A. D., \& Senne, C. M. (2019). A spatial fuzzy multicriteria analysis of accessibility: a case study in Brazil. Sustainability, 11(12), 3407. http://dx.doi.org/10.3390/su11123407.

Lyu, H., Shen, S., \& Arulrajah, A. (2018). Assessment of geohazards and preventative countermeasures using AHP incorporated with GIS in Lanzhou, China. Sustainability, 10(2), 304. http://dx.doi.org/10.3390/su10020304.

Malczewski, J. (2004). GIS-based land-use suitability analysis: a critical overview. Progress in Planning, 62(1), 3-65. http://dx.doi.org/10.1016/j.progress.2003.09.002.

Mardani, A., Jusoh, A., \& Zavadskas, E. (2015). Fuzzy multiple criteria decision-making techniques and applications: two decades review from 1994 to 2014. Expert Systems with Applications, 42(8), 4126-4148.

http://dx.doi.org/10.1016/j.eswa.2015.01.003.

Muravev, D., Hu, H., Zhou, H., \& Pamucar, D. (2020). Location optimization of CR express international logistics centers. Symmetry, 12(1), 143. http://dx.doi.org/10.3390/sym12010143.

Muravev, D., Rakhmangulov, A., Hu, H., \& Zhou, H. (2019). The introduction to System dynamics approach to operational efficiency and sustainability of dry port's main parameters. Sustainability, 11(8), 2413. http://dx.doi.org/10.3390/su11082413.

Nguyen, L., \& Notteboom, T. A. (2016). Multi-criteria approach to dry port location in developing economies with application to Vietnam. The Asian Journal of Shipping and Logistics, 32(1), 23-32. http://dx.doi.org/10.1016/j.ajsl.2016.03.003.

Notteboom, T. (2011). An application of multi-criteria analysis to the location of a container hub port in South Africa. Maritime Policy \& Management, 38(1), 51-79. http://dx.doi.org/10.1080/03088839.2010.533710.

Novaes, A. G., \& Vieira, H. F. D. (1996). O nível de serviço logístico portuário sob a ótica dos exportadores. Revista Gestão e Produção, 3(3), 290-301. http://dx.doi.org/10.1590/S0104-530X1996000300005.

Parry, J. A., Ganaie, S. A., \& Sultan Bhat, M. (2018). GIS based land suitability analysis using AHP model for urban services planning in Srinagar and Jammu urban centers of J\&K. India. Journal of Urban Management, 7(2), 46-56. http://dx.doi.org/10.1016/j.jum.2018.05.002.

Ramalho, A., \& Beek, K. L. (1995). Sistema de avaliação da aptidão agrícola das terras (3. ed.). Rio de Janeiro: EMBRAPA-CNPS.

Roso, V. (2007). Evaluation of the dry port concept from an environmental perspective: a note. Transportation Research Part D, Transport and Environment, 12(7), 523-527. http://dx.doi.org/10.1016/j.trd.2007.07.001.

Roso, V., Woxenius, J., \& Lumsden, K. (2009). The dry port concept: connecting container seaports with the hinterland. Journal of Transport Geography, 17(5), 338-345. http://dx.doi.org/10.1016/j.jtrangeo.2008.10.008.

Saad, S. M., \& Bahadori, R. (2019). Development of a Dynamic Information Fractal Framework to Monitor and Optimise Sustainability in Food Distribution Network. International Journal of Food Engineering, 16(5-6), 20180061. http://dx.doi.org/10.1515/ijfe-2018-0061. 
Saaty, T. L. (1980). The analytic hierarchy process. New York: McGraw Hill.

Saaty, T. L. (2008). Decision making with the analytic hierarchy process. International Journal of Services Sciences, 1(1), 83-98. http://dx.doi.org/10.1504/IJSSCI.2008.017590.

Souza, M. L., \& Rodrigues, G. B. (2004). Planejamento urbano e ativismos sociais. São Paulo: Unesp.

Tobias, M. S. G., Ramos Rui, A. R., \& Rodrigues, D. S. (2013). Spatial Analysis of accessibility to support decisionmaking in urban investments: a case in Amazonia-Brazil. In Proceedings of the 13th World Conference Transport Research (WCTR) (pp. 1-10). Leeds: WCTR Society.

Wang, C., \& Wei, J. (2008). Research on the dry port location of Tianjin port based on analytic network process. In Proceedings of the 2008 International Seminar on Business and Information Management (pp. 75-78). Piscataway: IEEE. http://dx.doi.org/10.1109/ISBIM.2008.74.

Zhu, B., Zhu, X., Zhang, R., \& Zhao, X. (2019). Study of multiple land use planning based on the coordinated development of wetland farmland: a case study of Fuyuan City, China. Sustainability, 11(1), 271. http://dx.doi.org/10.3390/su11010271.

\section{Editor: Fábio Duarte}

Received: Oct. 21, 2019

Approved: June 21, 2020 